$\mathrm{K}$

STUDIA Z PRAWA WYZNANIOWEGO

Tom $23-2020$

DOI: https://doi.org/10.31743/spw.9772

\title{
OGRANICZANIE WOLNOŚCI RELIGIJNEJ W PIERWSZYM OKRESIE PANDEMII COVID-19 W ŚWIETLE ORZECZNICTWA AMERYKAŃSKICH SĄDÓW
}

\section{Streszczenie}

W artykule przedstawiono i poddano analizie orzeczenia amerykańskich sądów federalnych w zakresie ograniczeń wolności religii w początkowym okresie pandemii COVID-19. Przedmiotem kontroli sądów były przepisy zakazujące publicznych zgromadzeń religijnych lub ograniczające liczbę ich uczestników. Autor podziela stanowisko tej części sądów, które przyjęły, że przepisy wprowadzające surowsze obostrzenia dla świątyń i zgromadzeń religijnych niż względem innych porównywalnych miejsc i świeckich zgromadzeń, dla swej konstytucyjności powinny realizować kluczowy interes i być środkiem proporcjonalnym. O ile ochrona zdrowia publicznego stanowi kluczowy interes władzy, o tyle wydaje się, że całkowity zakaz liturgii i nabożeństw z udziałem wiernych czy ustalenie liczby uczestników aktów kultu na poziomie kilku osób naruszają kryterium najmniej restrykcyjnego środka. Decydując o tym, jakie formy społecznej aktywności i działalności wyłączyć spod zakazu zgromadzeń publicznych, władza nie może dyskryminująco zakładać, że praktyki religijne są czymś drugorzędnym i mało pilnym, tym bardziej jeśli ta sama władza za istotną (essential) czy pierwszej potrzeby (life sustaining) uznaje działalność np. sklepów monopolowych bądź centrów handlowych.

Słowa kluczowe: wolność religii; COVID-19; Konstytucja Stanów Zjednoczonych; orzecznictwo sądów federalnych; Stany Zjednoczone; SARS-CoV-2

* Dr hab., prof. UR, Zakład Nauk Historyczno i Teoretycznoprawnych, Instytut Nauk Prawnych, Uniwersytet Rzeszowski, ul. Grunwaldzka 13, 35-068 Rzeszów, e-mail: gmaron@ur.edu.pl. ORCID 0000-0002-3861-9103. 


\section{WPROWADZENIE}

Pandemia koronawirusa SARS-CoV-2 (dalej: koronawirus), która wybuchła na przełomie 2019 i 2020 r., oraz wywoływana nim choroba COVID-19 stały się jednym z największych współczesnych wyzwań dla państw i społeczeństw. W istotnym stopniu wpłynęły na politykę, gospodarkę, naukę, kulturę, stosunki społeczne na całym świecie. Głównym sposobem przeciwdziałania rozprzestrzeniania się koronawirusa stało się ograniczanie interpersonalnych kontaktów. Wśród wielu obszarów aktywności społecznej, na których zaciążyły wdrożone środki bezpieczeństwa, znalazły się zbiorowe praktyki religijne ${ }^{1}$. Organy władzy w poszczególnych państwach motywowane troską o życie i zdrowie obywateli przyjęły przepisy nakazujące czasowe zamknięcie świątyń dla celów zbiorowego kultu religijnego lub wprowadziły restrykcyjne limity odnośnie do liczby osób mogących uczestniczyć w liturgii czy religijnych nabożeństwach. Rozwiązania te w jednych krajach implementowano bez szerszego społecznego rezonansu, w innych wzbudziły one kontrowersje i polemikę. Część osób, nie kwestionując samej potrzeby reglamentowania interpersonalnych kontaktów, w tym w ramach aktów kultu, zaczęła wysuwać obiekcje wobec proporcjonalności zastosowanych środków wobec celu w postaci zapobiegania nowym zarażeniom, np. podając w wątpliwość sensowność czy racjonalność obostrzenia, w myśl którego w kościele swobodnie mieszczącym kilkaset osób, liczbę wiernych dopuszczonych do uczestnictwa w nabożeństwie ustalono na poziomie 5 osób. Zastrzeżenia, a nawet kategoryczna krytyka ograniczania kolektywnych praktyk religijnych nasilały się w sytuacji, gdy obostrzenia dotyczące zgromadzeń religijnych były surowsze wobec innych niż miejsca kultu skupisk ludzkich, np. w obrębie centrum handlowego czy kasyna. W niektórych państwach osoby wierzące, uznając ingerencję władzy w ich wolność religijną za nadmierną i dyskryminującą, podjęły na drodze sądowej próby zakwestionowania legalności przepisów dających umocowanie dla tej ingerencji. Kra-

1 Corbin 2020. 
jem, którego sądy najczęściej stawały przed koniecznością oceny prawa ograniczającego wolność religijną w okresie pandemii COVID-19, stały się Stany Zjednoczone.

W niniejszym opracowaniu analizie poddano amerykańskie orzecznictwo dotyczące kolizji wolności religijnej jednostki z interesem publicznym w postaci ochrony życia i zdrowia obywateli ${ }^{2} \mathrm{w}$ stanie pandemii koronawirusa. Materiałem badawczym uczyniono judykaty sądów federalnych, które o wiele częściej niż sądy stanowe procedowały w przedmiocie omawianego zagadnienia. Uwzględniono orzeczenia wydane od końca marca do końca maja 2020 r. $^{3}$, czyli w pierwszym okresie rozwoju pandemii w Stanach Zjednoczonych, charakteryzującym się intensywnością wprowadzanych wówczas restrykcji praw i wolności obywatelskich. Chronologicznie jednym z ostatnich judykatów wziętych pod uwagę jest postanowienie Sądu Najwyższego USA z dnia 29 maja 2020 r., będące pewnym zwieńczeniem czy podsumowaniem wcześniejszej praktyki orzeczniczej na tym etapie rozwoju pandemii, choć nie „ostatnim słowem” tego sądu.

Tytułowa tematyka, jakkolwiek rozpatrywana w odniesieniu do i przez pryzmat amerykańskiego porządku prawnego, może komparatystycznie stanowić źródło cennych wskazówek dla podmiotów władzy publicznej i obywateli poza Stanami Zjednoczonymi. Jak powyżej wskazano, pandemia COVID-19 ma wymiar globalny, podobnie jak towarzyszący jej problem optymalnego wyważenia zdrowia publicznego z obywatelskimi wolnościami, włącznie ze swobodą praktyk religijnych. Doświadczenia amerykańskiego orzecznictwa mogą być także wartościowym punktem odniesienia dla organów władzy, w tym judykatywy, gdyby w przyszłości doszło do wybuchu kolejnych pandemii skutkujących potrzebą ograniczenia praw podstawowych jednostki.

2 Zob. szerzej Hodge 2015, 546-549.

3 Pierwsza bezskuteczna próba zakwestionowania na drodze sądowej przepisów ograniczających zgromadzenia, w tym te religijne, z powołaniem się na wolność religijną miała miejsce przed stanowym sądem w New Hampshire. Sąd 25 marca 2020 r. orzekł, że rozporządzenie zakazujące zgromadzeń powyżej 50 osób było konstytucyjne. Binford et al. v. Sununu, No. 217-2020-CV-00152 (N.H. Sup. Ct. Mar. 25, 2020). 
2. OGÓLNE ZASADY OCHRONY WOLNOŚCI RELIGIJNEJ I JEJ OGRANICZANIA W AMERYKAŃSKIM PORZĄDKU PRAWNYM

Zadanie zwalczania pandemii COVID-19 w Stanach Zjednoczonych przypadło przede wszystkim władzy stanowej, a konkretnie stanowej władzy wykonawczej na czele $\mathrm{z}$ gubernatorem. W działaniach ukierunkowanych na przeciwdziałanie rozprzestrzenianiu się koronawirusa partycypowały także organy władzy lokalnej na poziomie miast i hrabstw (county). Władza federalna zaangażowała się z kolei w niwelowanie skutków kryzysu gospodarczego. W związku z pandemią wydano szereg rozporządzeń wykonawczych (executive order) istotnie ograniczających prawa i wolności obywatelskie, w tym wolność religijną. Za naruszenie przepisów przewidziano nie tylko sankcje administracyjne, ale i karne ${ }^{4}$.

Rozwiązania przyjęte $\mathrm{w}$ poszczególnych stanach istotnie różniły się między sobą, w tym w odniesieniu do zgromadzeń religijnych. Postać rozporządzeń wykonawczych ulegała też intensywnym zmianom wraz z dynamicznym rozwojem sytuacji pandemicznej. W odstępach kilkunastu czy nawet kilku dni gubernatorzy wydawali nowe rozporządzenia wykonawcze zastępujące te dotychczasowe. W niektórych stanach początkowo całkowicie zakazano zgromadzeń religijnych (np. Kalifornia, Illinois, Nowy York). W innych ograniczono liczbę uczestników religijnych nabożeństw, zwykle do 10 osób (np. Kansas, Karolina Północna). W jeszcze innych stanach zgromadzenia religijne wyłączono spod zakresu obowiązywania przepisów dotyczących społecznego dystansu i minimalizowania mobilności (reguła stay-at-home) ${ }^{5}$, tym samym umożliwiając uczestnictwo w tych zgromadzeniach na dotychczasowych zasadach, tyle że z zachowaniem wymogów higienicznych (np. Teksas, Floryda) ${ }^{6}$.

4 Pierwsza sprawa kryminalna za naruszenie zakazów zgromadzeń religijnych dotyczyła pastora z Florydy, Rodney'a Howard-Browne’a, aresztowanego za bezprawne zgromadzenie i naruszenie zasad bezpieczeństwa zdrowotnego. D. Burke, Police arrest Florida pastor for holding church services despite stay-at-home order, https://www.cnn. com/2020/03/30/us/florida-pastor-arrested-river-church/index.html [dostęp: 11.08.2020].

5 Reiss, Thomas 2020.

6 V. Villa, Most states have religious exemptions to COVID-19 social distancing rules, https://www.pewresearch.org/fact-tank/2020/04/27/most-states-have-religious-exemptionsto-covid-19-social-distancing-rules/ [dostęp: 11.08.2020]. 
Osoby kontestujące na drodze sądowej przepisy zakazujące czy ograniczające możliwość udziału w zgromadzeniu religijnym zwykle powoływały się na ich sprzeczność z konstytucyjną zasadą wolności religijnej (Free Exercise Clause) wyrażoną w pierwszej poprawce do federalnej ustawy zasadniczej (,Żadna ustawa Kongresu nie może [...] zabronić swobodnego praktykowania [religii]") ${ }^{7}$. Zasada ta poprzez 14. poprawkę ma zastosowanie także do władzy stanowej i lokalnej, o czym przesądził Sąd Najwyższy w 1940 r. ${ }^{8}$ Skarżący oponowali rozporządzeniom wykonawczym także z powołaniem się na stanowe ustawy wzmacniające ochronę wolności religijnej (Religious Freedom Restoration Act) ${ }^{9}$. O wiele rzadziej w pozwach przywoływano konstytucyjną wolność zgromadzeń, również z 1. poprawki do federalnej ustawy zasadniczej ${ }^{10}$.

Ze względu na to, że sądowa merytoryczna całościowa ocena konstytucyjności kwestionowanych przepisów trwa zwykle rok lub dłużej, skarżący zwracali się do sądu o wydanie postanowienia czasowo wstrzymującego stosowanie zaskarżonych przepisów (temporary restraining order lub preliminary injunction), które do pewnego stopnia przypomina znaną polskiemu

7 Konstytucja Stanów Zjednoczonych Ameryki, tłum. Andrzej Pułło, Warszawa: Wydawnictwo Sejmowe 2002.

8 Cantwell v. Connecticut, 310 U.S. 296, 303 (1940).

9 Conklin 2020.

10 Zasadniczo przepisów regulujących zgromadzenia religijne nie kwestionowano z powołaniem się na zasadę neutralności religijnej państwa (Establishment Clause), choć w niektórych sprawach wydaje się, że byłoby to merytorycznie zasadne. Przykładowo rozporządzenie wykonawcze gubernatora Karoliny Północnej w drodze wyjątku dopuszczało przebywanie w świątyniach więcej niż 10 osób, przy udowodnieniu, że zgromadzenie takie nie może mieć miejsca na zewnątrz, np. gdy „konkretne przekonania religijne nakazują, aby wszystkie czy niektóre nabożeństwa religijne odbywały się w pomieszczeniu i z udziałem większej niż 10 liczby osób". W czasie postępowania sądowego przedstawiciel gubernatora wskazał, że o miejscu właściwym dla konkretnego nabożeństwa religijnego miałby decydować szeryf lub inny urzędnik. Wyjaśnienie to sąd uznał za ,zadziwiające”. Berean Baptist Church v. Roy Cooper, No. 4:20-CV-81-D (E.D.N.C. May 16, 2020). Podejmowanie przez funkcjonariuszy decyzji w oparciu o interpretację doktryny religijnej pozostaje sprzeczne z zasadą neutralności religijnej państwa. Jak jednak zaznaczono, warunkiem wydania temporary restraining order jest poniesienie przez skarżącego nieodwracalnej szkody. Wykazanie naruszenia Establishment Clause, w przeciwieństwie do naruszenia Free Exercise Clause, nie pozostaje zaś - w omawianym kontekście - w związku z poniesieniem szkody przez kościół czy jego wiernych. 
porządkowi prawnemu instytucję zabezpieczenia powództwa. Należy mieć jednak na uwadze, że amerykańskie sądy, dysponując kompetencją kontroli konstytucyjności prawa (judicial review), mogą poprzez wskazaną kategorię postanowień zawieszać stosowanie aktów normatywnych. Temporary restraining order tym różni się od preliminary injunction, że w przedmiocie jego wydania sąd decyduje bezzwłocznie, nawet bez konieczności przedstawienia i rozpoznania argumentacji strony pozwanej (in concreto gubernatora czy organów władzy lokalnej). Zwykle obowiązuje przez 14 dni. Z kolei preliminary injunction jest wydawany po zapoznaniu się przez sąd z argumentacją obu stron i może obowiązywać do końca procedowania sprawy, czyli jej rozstrzygnięcia ad rem. Obie instytucje ściśle się ze sobą wiążą. Przesłanki ich zastosowania są generalnie takie same. Niedługo po wydaniu temporary restraining order $\mathrm{w}$ tej samej sprawie sąd może wydać preliminary injunction. W sytuacji gdy sąd pierwszej instancji (federalny sąd okręgowy) odmówił temporary restraining order, sąd odwoławczy (federalny sąd apelacyjny) może przyznać preliminary injunction ${ }^{11}$.

Wydanie obu kategorii postanowień uzależnione jest od spełnienia łącznie 4 warunków. Po pierwsze, sąd bada, czy występuje prawdopodobieństwo rozstrzygnięcia sprawy ad meritum na korzyść strony wnioskującej o zabezpieczenie roszczeń. W kontekście tytułowej problematyki chodzi o ustalenie, czy prawdopodobnym jest, że zaskarżone przepisy w sposób niekonstytucyjny ingerują w wolność religijną. Po drugie, sąd ocenia, czy skarżący w przypadku niewydania tymczasowego postanowienia poniesie nieodwracalną szkodę. Po trzecie, sąd ma na uwadze, czy szkody grożące skarżącemu przewyższają te, które ewentualnie staną się udziałem drugiej strony na skutek zabezpieczenia powództwa (balance of equities). W końcu, wydanie tymczasowego postanowienia musi leżeć $\mathrm{w}$ interesie publicznym ${ }^{12}$.

W praktyce orzeczniczej kluczowa jest pierwsza przesłanka, co znajduje swój wyraz w uzasadnieniu postanowienia sądu. O ile rozważania sądu w przedmiocie tego, czy zaskarżone przepisy lub praktyka władz są niekonstytucyjne obejmują średnio kilka czy kilkanaście stron, o tyle

11 Rule 65 Federal Rules of Civil Procedure. Zob. też 42 U.S. Code $§ 1983$.

12 Zob. Stoll-DeBell, Dempsey, Dempsey 2009. 
pozostałym trzem wymogom sądy poświęcają zwykle zaledwie jeden lub dwa akapity tekstu judykatu.

Pomimo to, że sąd wydając postanowienie o zabezpieczeniu powództwa $\mathrm{w}$ formie wstrzymania stosowania zaskarżonych przepisów nie przesądza definitywnie o ich niekonstytucyjności, to jednak bardzo rzadko zdarza się, aby w późniejszym wyroku doszedł do odmiennych wniosków. Mając to na uwadze oraz dla zwięzłości i lepszej czytelności tekstu, poniżej - w kontekście poszczególnych przywołanych orzeczeń - będzie mowa o stwierdzeniu konstytucyjności lub niekonstytucyjności przepisów, choć w sensie ścisłym sądy miały na uwadze prawdopodobieństwo takiego właśnie rozstrzygnięcia przy przyszłej ocenie sprawy co do meritum.

W amerykańskim porządku prawnym wyróżnić można dwa podstawowe poziomy prawnej ochrony wolności religijnej jednostki, tj. konstytucyjny i ustawowy. Tekstualnie lakoniczny fragment 1. poprawki do federalnej ustawy zasadniczej dotyczący wolności religijnej doczekał się bardzo obszernej i ciągle ewoluującej interpretacji w orzecznictwie, na czele z case law Sądu Najwyższego USA. Wolność religijna jest gwarantowana także w stanowych konstytucjach ${ }^{13}$.

De lege lata zakres ochrony konstytucyjnej wolności religijnej wyznacza zwłaszcza precedensowe orzeczenie Sądu Najwyższego z 1990 r. w sprawie Employment Division v. Smith ${ }^{14}$, rozwinięte w wydanym trzy lata później wyroku w sprawie Church of the Lukumi Babalu Aye, Inc. v. City of Hialeh ${ }^{15}$. Zgodnie z oboma wyrokami nie jest sprzeczne z ustawą zasadniczą neutralne religijnie prawo o ogólnym zastosowaniu (generally applicable), które ubocznie ogranicza wolność religijną. Prawo takie podlega kontroli według standardu racjonalności, co zwykle prowadzi do wniosku o jego konstytucyjności. Natomiast prawo dyskryminujące praktyki religijne do swojej konstytucyjności powinno realizować kluczowy (compelling) interes władzy i być środkiem proporcjonalnym (dosłow-

13 O orzecznictwie Sądu Najwyższego w sprawach z zakresu zasady wolności religijnej i zasady religijnej neutralności państwa zob. np. McConnell, Berg, Lund 2016; Greenawalt 2009; z polskiej literatury np. Kudła 2018; Potz 2015; Małajny 1992.

14 Employment Division v. Smith, 494 U.S. 872 (1990).

15 Church of the Lukumi Babalu Aye, Inc. v. City of Hialeh, 508 U.S. 520 (1993). Zob. Laycock, Collis 2016, 1-27. 
nie „wąsko skrojonym” - narrowly tailored) wobec tego interesu ${ }^{16}$. Proporcjonalność jest tu rozumiana jako posłużenie się środkiem co do zasady najmniej restrykcyjnym.

Dyskryminacyjny charakter prawa może przybrać różne formy. Najbardziej jaskrawym, a jednocześnie najrzadszym przykładem są przepisy ograniczające wprost i jedynie religijną aktywność. Prawem dyskryminacyjnym mogą być również przepisy na pierwszy rzut oka neutralne. Takiej natury są przepisy reglamentujące praktyki religijne, jak i niereligijne, w sytuacji gdy prawo to spod obostrzeń wyłącza różne instancje aktywności niereligijnej pod istotnymi względami porównywalnej do doznających ograniczeń praktyk religijnych. Czym więcej wyjątków przewiduje akt normatywny, tym bardziej wątpliwy jego status jako neutralnego prawa o ogólnym zastosowaniu. Dyskryminacyjny charakter jest również udziałem przepisów tekstualnie prima facie neutralnych, lecz wydanych $\mathrm{z}$ antyreligijnej motywacji, tj. $\mathrm{z}$ niechęci wobec religii i osób wierzących in generale czy konkretnego wyznania.

W reakcji na wyrok Employment Division v. Smith Kongres USA uchwalił w 1993 r. ustawę Religious Freedom Restoration Act mającą wzmocnić ochronę wolności religijnej, a w zasadzie przywrócić stan prawny sprzed niniejszego precedensu. Zgodnie z ustawą władzy publicznej nie wolno w istotnym stopniu reglamentować prawa jednostki do postępowania inspirowanego szczerymi przekonaniami religijnymi, chyba że władza w sposób niewątpliwy wykaże, iż realizuje kluczowy interes i posłużyła się najmniej restrykcyjnymi środkami (tzw. test ścisły - strict scrutiny) ${ }^{17}$. W 1997 r. Sąd Najwyższy orzekł, że wskazana ustawa może mieć zastosowanie jedynie wobec władz federalnych, a Kongres obejmując nią władze stanowe i lokalne wykroczył poza swoje kompetencje ${ }^{18}$. Celem zachowania podwyższonego poziomu ochrony wolności religijnej parlamenty 21 stanów uchwaliły więc własne wersje Religious Freedom Restoration Act. W pozostałych stanach ustaw takich nie przyjęto ${ }^{19}$.

16 Church of the Lukumi, 508 U.S. 520, 553.

17 Taka też interpretacja konstytucyjnej wolności religijnej dominowała przed wyrokiem w sprawie Employment Division v. Smith, a począwszy od precedensu Sądu Najwyższego w sprawie Sherbert v. Verner, 374 U.S. 398 (1963).

18 City of Boerne v. Flores, 521 U.S. 507 (1997).

19 Stephens, Scheb 2008, 114. 
Rozporządzenia wykonawcze obliczone na zwalczanie pandemii COVID-19 nie były pierwszymi amerykańskimi przepisami wydanymi w stanie szczególnego zagrożenia zdrowia publicznego, których konstytucyjność kwestionowano na drodze sądowej w Stanach Zjednoczonych. W 1905 r. federalny Sąd Najwyższy w sprawie Jacobson v. Massachusetts utrzymał w mocy konstytucyjność przepisów stanu Massachusetts i wydanych na ich podstawie przepisów miasta Cambridge, wprowadzających obowiązkowe pod groźbą grzywny szczepienia przeciwko ospie w okresie epidemii tej choroby. Ograniczenia wolności religijnej miały miejsce także w latach 1918-1919 w czasie masowych zachorowań na grypę hiszpańską, co również stanowiło przedmiot kontroli sądów ${ }^{20}$.

W sprawie Jacobson v. Massachusetts Sąd Najwyższy uznał, że w ,społeczeństwie odpowiedzialnym za bezpieczeństwo swoich członków, prawa jednostki w odniesieniu do jej wolności czasami mogą być - w obliczu poważnego zagrożenia - poddane takiemu ograniczeniu, egzekwowanemu przy pomocy racjonalnych regulacji, jakiego może wymagać bezpieczeństwo interesu publicznego". Zajął też stanowisko, iż nie do niego należy ocena, które środki „są najbardziej skuteczne w ochronie społeczeństwa przed chorobą". Zakwestionowanie rozwiązań przyjętych przez władze miasta Cambridge byłoby po jego stronie „uzurpowaniem sobie funkcji innej gałęzi władzy”. Sąd zastrzegł jednak, że władzy prawodawczej i wykonawczej nie przysługuje pełna swoboda czy dowolność w ochronie zdrowia publicznego. Władza może bowiem korzystać ze swoich kompetencji „W tak arbitralny, nieracjonalny sposób, albo tak dalece wykraczać poza to co racjonalnie wymagane dla bezpieczeństwa społeczeństwa”, iż wręcz zmusza sąd do interwencji w ochronie praw jednostki. Jeśli przepisy ustanowione dla ochrony zdrowia publicznego „nie posiadają realnego bądź istotnego związku” z tym celem, albo „niewątpliwie stanowią zwykłą, namacalną inwazję w prawa chronione ustawą zasadniczą, to obowiązkiem sądu jest wydać rozstrzygnięcie, a tym samym nadać moc Konstytucji”21.

20 Zob. M. Brown, Coronavirus and Church Closures: Will the COVID-19 Gathering Bans Survive Free Exercise Challenges?, https://papers.ssrn.com/sol3/papers.cfm?abstract_ $\mathrm{id}=3580135$ [dostęp: 11.08.2020].

21 Jacobson v. Massachusetts, 197 U.S. 11, 28-31 (1905). Zob. Farber 2020. 
3. STUDIUM ORZECZEŃ FEDERALNYCH SĄDÓW OKRĘGOWYCH I APELACYJNYCH W ZAKRESIE REGLAMENTACJI WOLNOŚCI RELIGIJNEJ W OKRESIE PANDEMII COVID-19

W uwzględnionym przedziale czasowym sądy federalne wydały co najmniej 31 orzeczeń w przedmiocie wstrzymania stosowania - jako potencjalnie niekonstytucyjnych - przepisów ograniczających lub zakazujących udziału $\mathrm{w}$ zgromadzeniach religijnych ${ }^{22}$. W tej kwestii stanowisko zajęły sądy wszystkich trzech szczebli sądownictwa federalnego, dokładnie 16 sądów okręgowych, 5 sądów apelacyjnych i Sąd Najwyższy. W 22 orzeczeniach sądy odmówiły czasowego wstrzymania stosowania zaskarżonych przepisów. W 8 orzeczeniach sądy, w tym 2 sądy apelacyjne, przyznały rację skarżącym. W jednym przypadku sąd wstrzymał się z rozstrzygnięciem, czekając na rezultaty porozumienia obu stron.

Za niekonstytucyjne, gdyż sprzeczne z Free Exercise Clause, sądy uznały rozporządzenia wykonawcze zabraniające uczestniczenia w samochodowych mszach świętych na parkingu kościoła ${ }^{23}$, zakazujące osobistego uczestniczenia w aktach kultu wewnątrz świątyni ${ }^{24}$ czy ograniczające liczbę uczestników takiego zgromadzenia religijnego do 10 osób ${ }^{25}$.

Kluczową kwestią dla kierunku rozstrzygnięcia sądów okazało się porównanie charakteru zgromadzeń religijnych wobec innych form aktywności i miejsc odpowiednio zakazanych lub wyłączonych spod obostrzeń w związku z pandemią. Sądy, które uznały zaskarżone przepisy za naruszające konstytucyjną wolność religijną przyjęły, że zgromadzenia religijne są podobne do wielu rodzajów działalności, które te same przepisy w drodze wyjątku dopuszczały, zaliczając je do kategorii pierwszej potrzeby czy

22 J. M. Szymanski, Tracking Faith-Based Legal Challenges to Pandemic Orders, https://www.churchlawandtax.com/web/2020/may/tracking-pandemic-related-religious-liberty-cases.html [dostęp: 11.08.2020].

23 Maryville Baptist Church v. Beshear, 957 F.3d 610 (6th Cir. May 2, 2020); On Fire Christian Center v. Fischer, No. 3:20-CV-264-JRW (W.D. Ky. Apr. 11, 2020).

24 Maryville Baptist Church v. Beshear, No. 3:20-cv-278-DJH-RSE (W.D. Ky. May 8, 2020); Tabernacle Baptist Church v. Beshear, N. 3:20-cv-00033-GFVT (E.D. Ky. May 8, 2020); Roberts v. Neace, 958 F.3d 409 (6th Cir. May 9, 2020).

${ }^{25}$ First Baptist Church v. Kelly, 20-1102-JWB (D. Kan. Apr. 18, 2020); Berean Baptist Church v. Cooper. 
istotnych czynności (life sustaining, essential). W ocenie tych sądów, jeśli z zachowaniem zasad bezpieczeństwa (odstęp pomiędzy osobami, rygor sanitarny) mogą funkcjonować np. lotniska, dworce, biura, fabryki, pralnie, kancelarie prawnicze, biblioteki, punkty doradztwa księgowego, centra handlowe, sklepy spożywcze, sklepy monopolowe, sklepy z narzędziami, sklepy z bronią palną, hotele, restauracje, usługi architektury krajobrazu, myjnie samochodowe, psi fryzjerzy czy lodziarnie ${ }^{26}$, to również taka możliwość powinna być udziałem kościołów. Wskazane wyjątki łączą się bowiem z kontaktem pomiędzy ludźmi i niosą ze sobą - zdaniem sądów - podobny stopień zagrożenia dla zdrowia, co zakazane zbiorowe praktyki religijne ${ }^{27}$.

Skoro na gruncie prawa praktyki religijne i kościoły potraktowano odmiennie od świeckich zgromadzeń i miejsc, to prawo to nie może uchodzić za neutralne, np. przepisy zakazujące sprawowania samochodowych mszy świętych, ale już nie funkcjonowania restauracji bądź sklepów monopolowych w formule drive-through ${ }^{28}$. Prawo ujawnia brak neutralności, chroniąc aktywność świecką bardziej niż porównywalną religijną ${ }^{29}$. Tymczasem władza, realizując legitymowane cele, „nie może w sposób wybiórczy nakładać ciężary jedynie na postępowanie motywowane religijnym przekonaniem"30. Jak ujął to Sąd Apelacyjny dla 6 Okręgu, ani osoby wierzące, ani niewierzące nie mają prawa narażać społeczeństwa na choroby zakaźne. Tyle że stosowanie ograniczeń do jednej grupy ludzi, a wyłączenie z niej innych, nie tyle służy ochronie zdrowia publicznego, co ogranicza wolność religijną ${ }^{31}$.

Stwierdzenie, że zaskarżone przepisy nie są neutralne, ewentualnie nie posiadają też przymiotu prawa o ogólnym zastosowaniu, skutkowało

${ }^{26}$ Katalog ten przedstawia się różnie w poszczególnych stanach. Powyżej wymieniono zbiorczo listę obiektów i usług wyłączonych spod zakazów funkcjonowania czy spod ograniczeń ilościowych, jakie wymieniono w rozpatrywanych judykatach.

27 Roberts, 958 F.3d 409, 414.

28 On Fire Christian Center v. Fischer, s. 12. Zob. Wiley, Vladeck 2020, 189.

29 Roberts, 958 F.3d 409, 415.

30 Church of the Lukumi, 508 U.S. 543.

31 Maryville Baptist Church, 957 F.3d 610, 615. Sąd Apelacyjny dla 6 Okręgu ma rację twierdząc, że samo wymienienie z nazwy w przepisach zgromadzeń religijnych jako tych zakazanych, jeszcze per se nie świadczy o dyskryminacyjnym traktowaniu, skoro z nazwy wymieniono także inne formy aktywności, grupy osób czy miejsca. 
podjęciem oceny ich konstytucyjności z uwzględnieniem wspomnianego tzw. testu ścisłego. Jak już powyżej wskazano, zgodnie z tym standardem orzeczniczym przepisy prawne bądź praktyka postępowania władz publicznych nie naruszają ustawy zasadniczej, pomimo ograniczania praw i wolności konstytucyjnych, jeśli służą realizacji „kluczowego” interesu oraz są ,wąsko skrojone” pod realizację tego interesu. Innymi słowy, władza publiczna może posłużyć się środkami skutecznymi, a jednocześnie najmniej represyjnymi ${ }^{32}$.

Wszystkie sądy zgodnie uznały, że zwalczanie pandemii stanowi kluczowy interes władzy publicznej. Niektóre z nich przyjęły natomiast, iż poddane ich ocenie przepisy nie spełniają wymogu najmniej restrykcyjnego środka. Przepisy te są bowiem jednocześnie zakresowo zbyt wąskie i zbyt szerokie (underinclusive i overbroad). Mają charakter zbyt wąski, skoro nie obejmują takich potencjalnie niebezpiecznych z punktu widzenia rozprzestrzeniania się COVID-19 form aktywności - a uznanych przez władze za „istotne” czy „podtrzymujące życie” - jak przykładowo działalność sklepów monopolowych czy lodziarni. Jak sarkastycznie dano temu wyraz w jednym z orzeczeń, ,[j]eśli piwo jest istotne, to i Wielkanoc również"33. Kontrolowane przepisy są zarazem zakresowo zbyt szerokie, skoro do realizacji celu w postaci ochrony zdrowia publicznego podczas zgromadzeń religijnych użyto środków bardziej represyjnych niż to konieczne i surowszych niż te stosowane do innych porównywalnych niereligijnych zgromadzeń. Jak podnosi sędzia Daniel Collins, nie sposób uznać, że całkowity zakaz zgromadzeń religijnych wewnątrz świątyni spełnia wymóg najmniej restrykcyjnego środka. Można było przecież wprowadzić obowiązek noszenia przez wiernych maseczek, zakaz obejmowania się, podawania rąk czy trzymania się za ręce. Odnosząc przepisy do zachowań łączących się z ryzykiem, a nie zakazując wydarzeń religijnych, w ramach których takie zachowania mają miejsce, władza mogłaby zrealizować swoje cele bez nadmiernego uszczuplenia wolności religijnej ${ }^{34}$.

32 Fallon 2019, 54-66.

33 On Fire Christian Center v. Fischer, s. 13.

34 South Bay United Pentecostal Church v. Newsom, 959 F.3d 938, 946 (9th Cir. May 22, 2020) (Collins, dissenting). 
Uznawszy niekonstytucyjność przepisów - a dokładniej mówiąc prawdopodobieństwo takiej niekonstytucyjności - sądy bez szerszej argumentacji przyjęły, że także trzy pozostałe wymogi temporary restraining order i preliminary injunction zostały spełnione. W niemożności uczestniczenia we mszy świętej doszukały się nieodwracalnej szkody dla wiernych. Powołały się w tym względzie na jednoznaczne orzecznictwo Sądu Najwyższego, w myśl którego „utrata wolności z Pierwszej Poprawki, nawet przez bardzo krótki okres, niewątpliwie stanowi nieodwracalną szkodę"35. Potraktowanie zgromadzeń religijnych tak jak innych zgromadzeń wyjętych spod zakazu i przy przestrzeganiu takiego samego rygoru sanitarnego uznano za nieprzynoszące szkody pozwanych władzom. W końcu stwierdzono, że możliwość publicznych i zbiorowych praktyk religijnych leży w interesie publicznym, ilekroć odbywają się one z zachowaniem zasad bezpieczeństwa tożsamych wobec tych dotyczących dozwolonych form działalności gromadzących osoby.

Większość spraw, w których z powołaniem się na konstytucyjną wolność religijną kwestionowano przepisy zakazujące lub reglamentujące zgromadzenia religijne w związku z pandemią, zakończyła się utrzymaniem ich mocy. Sądy dochodzące do takich rozstrzygnięć podkreślały, że COVID-19 stanowi szczególne zagrożenie dla zdrowia publicznego, a przeciwdziałanie tej chorobie wymaga działań skutkujących ograniczeniem niektórych konstytucyjnych praw i wolności. Rozporządzenia wykonawcze gubernatorów czy burmistrzów wprowadzające liczne zakazy i obostrzenia są w ich ocenie neutralnym prawem o ogólnym zastosowaniu w rozumieniu Employment Division v. Smith. Przepisów tych nie ustanowiono z motywów antyreligijnych. Nie dyskryminują też one arbitralnie bądź selektywnie praktyk religijnych. Zakazy stosowane wobec kościołów są takie same, jak te dotyczące np. kin, teatrów, sal widowiskowo-koncertowych. We wskazanych przypadkach chodzi o gromadzenie się osób przez dłuższy czas w jednym miejscu, czemu towarzyszy mówienie czy śpiewanie, co tym samym zwiększa ryzyko przenoszenia koronawirusa. Zdaniem tej grupy sądów zgromadzenia religijne nie są podobne do takich dopuszczonych w drodze wyjątków form społecznej interakcji, jak choćby robienie zakupów w sklepie. W czasie

35 Elrod v. Burns, 427 U.S. 347, 373 (1976). 
zakupów ludzie nie grupują się i nie pozostają dłużej w tym samym miejscu. Uznając neutralność zaskarżonych przepisów sądy te w konsekwencji stwierdzały ich konstytucyjność. Często powoływały się przy tym na precedens ze sprawy Jacobson ${ }^{36}$, podkreślając, że nie do nich należy ocena optymalności i efektywności poszczególnych rozwiązań przyjętych przez władzę wykonawczą, które to rozwiązania prima facie pozostają w racjonalnym związku z przeciwdziałaniem pandemii. Sięgały też do rozumowania właściwego dla wykładni funkcjonalnej, wskazując że w swoich rozstrzygnięciach muszą kierować się praktyczną mądrością i mieć na uwadze ich społeczne skutki, tak aby konstytucja nie stała się aktem destrukcyjnym ${ }^{37}$.

Wolność religijna nie jest jedyną konstytucyjną wolnością czy prawem doznającą ograniczenia w okresie pandemii w USA. Przed amerykańskimi sądami kwestionowano - z różnym skutkiem - przepisy wydane w związku z COVID-19 jako pogwałcające także np. prawo do aborcji ${ }^{38}$ czy prawo przemieszczania się pomiędzy stanami ${ }^{39}$.

4. POSTANOWIENIE SĄDU NAJWYŻSZEGO Z DNIA 29 MAJA $2020 \mathrm{R}$.

W SPRAWIE SOUTH BAY PENTECOSTAL CHURCH V. NEWSOM

Rozbieżności pomiędzy poszczególnymi federalnymi sądami okręgowymi i apelacyjnymi co do oceny dopuszczalnego zakresu reglamentowania wolności religijnej w okresie pandemii znalazły swój wyraz także w postanowieniu Sądu Najwyższego USA z dnia 29 maja 2020 r. w sprawie South Bay Pentecostal Church v. Newsom. Sąd stosunkiem głosów 5-4 odrzucił wniosek jednego z kościołów o wstrzymanie stosowania wobec niego zarządzenia gubernatora Kalifornii, zgodnie z którym w miej-

36 Zob. Parmet 2020.

37 Zob. zwłaszcza Elim Romanian Pentecostal Church v. Pritzker, 962 F.3d 341 (7th Cir. May 16, 2020); South Bay United Pentecostal Church v. Newsom, 959 F.3d 938 (9th Cir. May 22, 2020); Bullock v. Carney, 806 F. App'x 157 (3rd Cir. May 30, 2020).

38 In re Abbott, 954 F.3d 772 (5th Cir. Apr. 7, 2020); In re Rutledge, 956 F.3d 1018 (8th Cir. Apr. 22, 2020).

39 Cameron v. Beshear, 3:20-cv-00023-GFVT (E.D. Ky., May 21, 2020). 
scach kultu religijnego mogły przebywać osoby w liczbie 1/4 pojemności budynku, nie więcej niż 100 osób.

O braku konsensusu wśród sędziów Sądu Najwyższego świadczy nie tylko rozłożenie się samych głosów, ale również brak uzasadnienia postanowienia. Do orzeczenia zgłoszono natomiast jedno krótkie zdanie zbieżne (concurrence) i jedno równie krótkie zdanie odrębne (dissent), które ujawniają główne różnice w rozumowaniu i argumentacji sędziów. Zdanie zbieżne przewodniczącego Sądu, Johna Robertsa, w dużym stopniu stanowi syntezę stanowiska tych federalnych sądów okręgowych i apelacyjnych, które afirmowały rozporządzenia wykonawcze władz stanowych skutkujące zakazaniem lub ograniczeniem zgromadzeń religijnych. Z kolei zdanie odrębne sędziego Bretta Kavanaugh, do którego przyłączyli się sędziowie Clarence Thomas i Neil Gorsuch, jest powtórzeniem głównych racji wskazywanych przez te sądy, które działania władz stanowych uznawały za nadmiernie ingerujące w wolność religijną.

W ocenie sędziego Robertsa rozporządzenie gubernatora Kalifornii ograniczające liczebność zgromadzeń religijnych wydaje się być zgodne z konstytucyjną zasadą wolności religijnej. Podobne, a nawet surowsze obostrzenia dotyczą porównywalnych świeckich zgromadzeń, w tym wykładów, koncertów, pokazów filmowych, widowisk sportowych, przedstawień teatralnych, tj. wydarzeń gromadzących dużą liczbę osób znajdujących się w bliskiej odległości przez dłuższy okres. Zdaniem Robertsa zaskarżone rozporządzenie nie obejmuje albo traktuje łagodniej pewne formy ludzkiej aktywności i działalności, które jednak nie przejawiają podobieństwa do nabożeństw religijnych. W sklepach spożywczych, bankach, pralniach ludzie nie gromadzą się w dużych grupach ani nie pozostają dłużej w bliskiej odległości od siebie.

Nie tylko rzekome niepodobieństwo reglamentowanych zgromadzeń religijnych z wyłączonymi spod ograniczeń innymi zgromadzeniami zostało przywołane przez sędziego Robertsa na rzecz konstytucyjności kwestionowanych przepisów stanowych. W zdaniu zbieżnym wyeksponowano zasadę podziału władz, podnosząc, że dobór optymalnych środków w zakresie ochrony życia i zdrowia obywateli w stanie epidemii należy do władzy wykonawczej a nie judykatywy. Jak wskazuje sędzia, „Nasza Konstytucja zasadniczo powierza «bezpieczeństwo i zdrowie społeczeństwa» ponoszącym polityczną odpowiedzialność urzędnikom państwa, «aby je 
strzec i chronić»»"40. W podejmowaniu działań „w obszarach obarczonych niepewnością medyczną i naukową" musi im przysługiwać znaczna swoboda $^{41}$. Rolą niepochodzących $\mathrm{z}$ wyborów sędziów federalnych nie jest prowadzenie polityki w zakresie zdrowia publicznego. Sądownictwo nie posiada w tym zakresie kompetencji, nie dysponuje potrzebną wiedzą specjalistyczną oraz nie podlega odpowiedzialności przed społeczeństwem.

Natomiast w ocenie sędziego Kavanaugh zaskarżone rozporządzenie gubernatora Kalifornii dyskryminuje miejsca kultu religijnego w porównaniu do innych miejsc gromadzących ludzi, w których prowadzona jest działalność czy są świadczone usługi o niereligijnym charakterze. Limitowi $25 \%$ miejsc nie podlegała aktywność np. fabryk, biur, restauracji, aptek, sklepów detalicznych, supermarketów, centrów handlowych, salonów dla zwierząt, księgarni, salonów fryzjerskich czy sklepów z marihuaną. Dyskryminacja ta przeczy konstytucji, skoro władzy publicznej nie wolno ,posługiwać się religią jako kryterium klasyfikacji przy nakładaniu obowiązków, kar, przywilejów bądź korzyści”"42. Co prawda władza realizuje kluczowy interes, chroniąc zdrowie obywateli w okresie pandemii COVID-19, ale „ograniczenia niezrozumiale stosowane do jednej grupy, a wyłączone wobec innej, w niewielkim stopniu sprzyjają tym celom, a znacząco obciążają wolność religijną" "43. W ocenie Kavanaugh władze Kalifornii nie uzasadniły innego traktowania zgromadzeń religijnych i szeregu świeckich przedsięwzięć.

Sędzia podkreśla, że kościół będący powodem w sprawie chce przestrzegać stanowych zasad dotyczących zachowania odstępu pomiędzy osobami i środków higieny, a stosowanych do porównywalnej świeckiej działalności. Kościół ten i jego wierni nie żądają przywilejów, a jedynie traktowania na równi z innymi. Jeśli limity osób w świątyniach są konieczne dla ochrony zdrowia publicznego, to takie same limity powinny być stosowane do innych miejsc gromadzących osoby ${ }^{44}$.

40 South Bay Pentecostal Church v. Newsom, 140 S. Ct. 1613, 1613 (2020) (Roberts, concurring), cytując Jacobson, 197 U. S. 38.

41 Ibidem, cytując Marshall v. United States, 414 U. S. 417, 427 (1974).

42 South Bay Pentecostal Church, 140 S. Ct. 1613, 1614 (Kavanaugh, dissenting), cytując McDaniel v. Paty, 435 U. S. 618, 639 (1978) (Brennan, J., concurring in judgment).

43 Ibidem, cytując Roberts, 958 F.3d 409, 414.

44 Ibidem. 
Już po wniesieniu sprawy do sądu i w związku z tym gubernator Kalifornii wydał nowe rozporządzenie łagodzące restrykcje nakładane na zgromadzenia religijne. Niewykluczone, że okoliczność ta zaważyła na rozstrzygnięciu Sądu Najwyższego. Gdyby sąd oceniał wcześniejszą postać przepisów całkowicie zakazujących osobistego uczestnictwa wiernych w nabożeństwach religijnych, to jego konkluzja odnośnie do konstytucyjności przepisów mogła być inna ${ }^{45}$.

W dniu 29 maja 2020 r. Sąd Najwyższy w sprawie Elim Romanian Church, et al. v. Pritzker odrzucił także wniosek innego kościoła o wstrzymanie stosowania przepisów, tym razem autorstwa gubernatora stanu Illinois. Postanowienie wydano bez uzasadnienia i jednomyślnie. Powodem takiego rozstrzygnięcia była faktyczna bezprzedmiotowość wniosku, w związku z tym, że dzień wcześniej władze stanowe wydały nowe przepisy, w dużym stopniu znoszące surowe restrykcje wobec zgromadzeń religijnych ${ }^{46}$.

45 W kolejnym postanowieniu, z dnia 24 lipca 2020 r., Sąd Najwyższy stosunkiem głosów 5-4 odrzucił wniosek jednego z kościołów w stanie Nevada o wstrzymanie stosowania do niego przepisów wydanych przez gubernatora, ograniczających liczbę uczestników zgromadzeń religijnych do 50 osób, bez względu na powierzchnię świątyni, pomimo to, że te same przepisy zezwalały na zajmowanie do $50 \%$ miejsc w takich lokalizacjach jak np. kasyna, siłownie czy kręgielnie. Calvary Chapel Dayton Valley v. Sisolak, 591 U. S. (2020). Do zmiany orzecznictwa Sądu Najwyższego w przedmiocie tytułowego zagadnienia doszło wraz z wejściem do składu Sądu nowej sędzi, Amy Coney Barrett, z dniem 27 października 2020 r. W postanowieniu z dnia 25 listopada 2020 r. Sąd Najwyższy wstrzymał stosowanie przepisów stanu Nowy York określających limit 10 i 25 osób mogących uczestniczyć w aktach kultu religijnego. Roman Catholic Diocese of Brooklyn v. Cuomo, No. 20A87 (U.S. Nov. 25, 2020). Zob. też analogicznie: Agudath Israel, et al. v. Cuomo, No. 20A90 (U.S. Nov. 25, 2020). Postanowieniem z dnia 5 lutego 2021 r. Sąd Najwyższy wstrzymał natomiast stosowanie przepisów stanu Kalifornia całkowicie zabraniających odbywania aktów kultu religijnego wewnątrz pomieszczeń. Utrzymał natomiast w mocy limit osób mogących uczestniczyć w aktach kultu na poziomie $25 \%$ pojemności budynku oraz zakaz śpiewania i wznoszenia okrzyków w ich trakcie. South Bay United Pentecostal Church v. Newsom, No. 20A136 (20-746) (U.S. Feb. 5, 2021). Podobnie w Harvest Rock Church, et al. v. Newsom, No. 20 A137 (U.S. Feb. 5, 2021) oraz w postanowieniu z dnia 26 lutego 2021 r.: Gateway City Church, et al. v. Newsom, No. 20A138 (U.S. Feb. 26, 2021).

46 Elim Romanian Church v. Pritzker, 590 U.S._(2020). 
5. WOLNOŚĆ RELIGIJNA W OKRESIE PANDEMII COVID-19: POMIĘDZY IUS ABSOLUTUM A IUS SECUNDARIUM

Przywołane orzecznictwo pokazuje trudność w proporcjonalnym wyważeniu wolności religijnej osób wierzących z interesem publicznym w postaci ochrony zdrowia obywateli. Szczera motywacja władzy publicznej, która z zaangażowaniem i oddaniem podejmuje działania w ekstraordynaryjnej sytuacji dla dobra powszechnego nie może jednak skutkować blankietowym przyznaniem decyzjom tej władzy swoistego immunitetu. Nie można zmuszać osób wierzących do bezkrytycznego akceptowania bezwzględnych zakazów czy istotnych ograniczeń w zakresie zgromadzeń religijnych, zwłaszcza wówczas gdy praktyki religijne wydają się być traktowane mniej przychylnie niż inne formy interpersonalnej ludzkiej aktywności i działalności, niosące nie mniejsze zagrożenia dla zdrowia publicznego.

We wspomnianych powyżej kilku sprawach sądy przyznały rację osobom kwestionującym przepisy reglamentujące możliwość uczestnictwa w religijnych nabożeństwach. W szeregu innych sprawach środowiska religijne uzyskiwały swoje cele poprzez samo wniesienie sprawy do sądu, jeszcze przed jej rozstrzygnięciem. W reakcji bowiem na pozew, gubernator czy władze lokalne zmieniały rozporządzenia wykonawcze, zezwalając na legalne odbywanie zbiorowych praktyk religijnych, zaliczając je do jednego z wielu wyjątków wyłączonych spod ogólnego zakazu zgromadzeń publicznych. Prawidłowość ta pokazuje, że nie zawsze postawa spolegliwości i ślepego zaufania do władzy i jej rozstrzygnięć stanowi najlepsze rozwiązanie. Kazus amerykański nie jest tu jedyny. We Francji możliwość publicznego sprawowania kultu religijnego w świątyniach została przywrócona w następstwie orzeczenia Rady Stanu ${ }^{47}$.

Te spośród amerykańskich sądów, które wstrzymały stosowanie przepisów ingerujących w wolność religijną, jednocześnie wyraźnie przyznawały, że prawa i wolności konstytucyjne, w tym wolność religijna, nie mają charakteru ius absolutum. W okresie szczególnego zagrożenia, jakim jest pandemia COVID-19, mogą być ograniczane. Konstytucja to

47 Rada Stanu Francji: zakaz zgromadzeń w miejscach kultu niezgodny z prawem, http://idziemy.pl/kosciol/rada-stanu-francji-zakaz-zgromadzen-w-miejscach-kultu-niezgodny-z-prawem/64319 [dostęp: 11.08.2020]. 
bowiem nie „pakt samobójczy”48, a prawo do swobodnego praktykowania religii „nie obejmuje narażania społeczeństwa na [...] choroby zakaźne, a w konsekwencji na chorobę czy śmierć"49. Nawet jednak w czasie epidemii „konstytucyjne prawa wciąż istnieją" ${ }^{50}$. Także wówczas „konstytucję należy chronić” ${ }^{51}$. „Nie istnieje pandemiczny wyjątek” wobec konstytucyjnej wolności religijnej ${ }^{52}$. W precedensie ze sprawy Jacobson stwierdzono, że uprawnienia władzy w przeciwdziałaniu zagrożeniu epidemicznemu nie są absolutne, nie można ich realizować „w arbitralny, nierozumny sposób” czy w sposób dalece wykraczający poza to, co „racjonalnie wymagane dla bezpieczeństwa publicznego" 53 .

Sądy uznające przepisy reglamentujące zbiorowe praktyki religijne za niekonstytucyjne zwróciły uwagę, że skarżące te przepisy kościoły i ich wyznawcy nie przejawiają postaw anarchistycznych czy nie ujawniają społecznego ekscepcjonalizmu. To, czego domagają się, to równe traktowanie. Nie chcą uchylać się od wytycznych w zakresie zdrowia publicznego, ale chcą w pełni wdrożyć zalecenia sanitarne podczas swoich nabożeństw. Sądy zezwalając na odbywanie zgromadzeń religijnych czyniły to właśnie pod warunkiem stosowania się do zasad bezpieczeństwa wymaganych prawem w stosunku do porównywalnych świeckich zgromadzeń ${ }^{54}$.

Wierni dochodzący w postępowaniu sądowym możliwości uczestniczenia $\mathrm{w}$ religijnych nabożeństwach nie są egoistycznymi, pretensjonalnymi, nieodpowiedzialnymi fanatykami. Powołując się na swoje konstytucyjne prawa spotykają się z niezrozumieniem, doświadczają pozamerytorycznej medialnej, społecznej, urzędowej krytyki ${ }^{55}$, agresji, a nawet przemocy.

48 Terminiello v. City of Chicago, 337 U.S. 1, 37 (1949) (Jackson, J., dissenting).

49 Prince v. Massachusetts, 321 U.S. 158, 166-67 (1944).

50 On Fire Christian Center v. Fischer, s. 15.

51 Tabernacle Baptist Church v. Beshear, s. 1.

52 Berean Baptist Church v. Cooper, s. 2.

53 Jacobson, 197 U.S. 28.

54 Roberts, 958 F.3d 409, 414; Maryville Baptist Church, 957 F.3d 610, 615; Berean Baptist Church v. Cooper, s. 15.

55 Zob. orzeczenie w sprawie First Pentecostal Church v. Holly Springs, No. 3:20CV119 M-P (N.D.Miss., May 14, 2020), w którym sędzia Michael Mills w sposób arogancki i mentorski ostro skrytykował domaganie się przez skarżących możliwości osobistego uczestniczenia w nabożeństwie religijnym. 
Przykładem jest podpalenie budynku kościoła wspólnoty zielonoświątkowców w Holly Springs w stanie Mississippi wraz z pozostawieniem na kościelnym parkingu graffiti o treści: „Założę się, że teraz zostaniecie w domu hipokryci”. Władze miasta, przeciwko któremu religijna wspólnota wystąpiła na drogę sądową, w reakcji na spalenie świątyni bezemocjonalnie wnioskowały o umorzenie postępowania jako bezprzedmiotowego (moot). Sędzia Don Willett stanowisko władz lokalnych określił w zdaniu zbieżnym do orzeczenia Sądu Apelacyjnego dla 5 Okręgu jako „haniebne” $(\text { shameful })^{56}$.

Władzy nie wolno z góry zakładać, że wierni w trakcie zgromadzeń religijnych nie będą stosować się do obostrzeń sanitarnych, przy jednoczesnym przekonaniu, że np. pracownicy i klienci w pralni czy w sklepie będą przestrzegać tam tych samych obostrzeń. Nie ma podstaw do tego, aby nie ufać uczestnikom wydarzeń religijnych w świątyni, a ufać osobom gromadzącym się w innym miejscu i w innych celach. Gubernator nie może zakładać najgorszego, gdy ludzie idą się modlić i zakładać to co najlepsze, gdy ludzie udają się do pracy czy wykonują inne czynności dnia codziennego. Zresztą wielokrotnie to są ci sami ludzie. Jeśli ktoś naruszy natomiast reguły bezpieczeństwa zdrowotnego, to władza może i powinna je egzekwować ${ }^{57}$.

Wstrzymaniu stosowania przepisów ograniczających wolność religijną nie towarzyszyło zanegowanie wysiłków podejmowanych przez władze stanowe i lokalne w walce $\mathrm{z}$ pandemią. Jeden $\mathrm{z}$ sądów wyraźnie zastrzegł, że nie wątpi w szczerość motywów tych, którzy w trosce o zdrowie publiczne zakazują zgromadzeń religijnych. Dodał jednak, że sama szczerość intencji nie legitymizuje nadmiernej ingerencji w konstytucyjne prawa i wolności jednostki. Nie wystarczy, że działania władzy są „o czystym sercu, jeśli prawo, które ona stanowi, w rzeczywistości wyróżnia religijną praktykę, poddając ją szczególnym ciężarom" ${ }^{58}$. Podobnie inny sąd zwrócił uwagę, że niekonstytucyjności przepisów nie warunkuje

56 First Pentecostal Church of Holly Springs v. City of Holly Springs, 959 F.3d 669, 671 (5th Cir. May 22, 2020) (Willett, concurring).

57 Maryville Baptist Church, 957 F.3d 610, 615; Roberts, 958 F.3d 409, 414; Berean Baptist Church v. Cooper, s. 16.

58 On Fire Christian Center v. Fischer, s. 14 cytując 508 U.S. at 559 (Scalia, J., concurring). 
niechęć, nietolerancja czy wrogość wobec religii po stronie tych, którzy te przepisy stanowili ${ }^{59}$.

Nieuprawnione jest ex ante twierdzenie o większym ryzyku zarażenia się COVID-19 w świątyniach niż w wielu innych miejscach (budynkach), w których ludziom zezwolono gromadzić się. Zasadność takiego przeświadczenia musi znajdować swój wyraz w dowodach, danych, argumen$\operatorname{tach}^{60}$. Nie wystarczy apriorycznie powzięte przekonanie w tym względzie. Sądy, kwestionując takie założenie, powoływały się na zdrowy rozsądek, życiowe doświadczenie. W uzasadnieniach swoich orzeczeń zadały wymowne pytania eksponujące niekonsekwencję i arbitralizm prawodawcy w zakresie adekwatności wydanych przepisów wobec przyświecającego im ratio legis: jeśli zasada odstępu pomiędzy osobami jest uważana za wystarczającą w hipermarkecie, to czemu nie w kościele ${ }^{61}$; dlaczego przyjęto, że bezpiecznie jest przebywać w samochodzie na parkingu przed sklepem monopolowym, ale już nie na parkingu przed kościołem?; dlaczego bezpiecznie jest chodzić pomiędzy sklepowymi regałami, ale już nie pomiędzy ławami kościelnymi?; dlaczego można bezpiecznie kontaktować się z kurierem, ale już nie z pastorem przy zachowaniu takich samych środków ostrożności w obu przypadkach? ${ }^{62}$

Z punktu widzenia przepisów zakazujących publicznych zgromadzeń nie posiada relewantności cel, dla którego ktoś decyduje się przebywać w konkretnym miejscu. Ryzyko zarażenia pozostaje bez związku z tym, czy ktoś pojawi się w świątyni, aby modlić się, w sklepie, aby zrobić zakupy czy na lotnisku, aby z niego udać się w podróż. „Ryzyko zarażenia zależy od społecznych interakcji na małej przestrzeni; dla wirusa nie ma znaczenia dlaczego ktoś znalazł się w danym miejscu”. Jeśli ryzyko warunkowane jest liczbą gromadzących się osób na określonej przestrzeni, to środkiem przeciwdziałania mu jest ustalenie limitu osób na nabożeństwie analogicznego do limitu obowiązującego w innych miejscach ${ }^{63}$.

59 Roberts, 958 F.3d 409, 413.

60 Berean Baptist Church v. Cooper, s. 16-17.

${ }_{61}$ Tabernacle Baptist Church v. Beshear, s. 10; Kentucky v. Beshear, N. 3:20-cv00033-GFVT (E.D. Ky. May 8, 2020).

62 Maryville Baptist Church, 957 F.3d 610, 615.

63 Ibidem. 
Sądy uznające konstytucyjność przepisów reglamentujących wolność religijną wydają się zbyt szeroko interpretować precedens ze sprawy $J a$ cobson. Nie bez racji sędzia Daniel Collins podnosi, że stosowanie rozumowania wyrażonego $\mathrm{w}$ tym precedensie do 1 . poprawki i innych postanowień ustawy zasadniczej, z wyłączeniem precedensu ze sprawy Lukumi, kłóci się z konstytucyjnym porządkiem USA. „Jeśliby przyjąć to skrajne stanowisko, to wówczas fiat stanowego gubernatora, a nie Konstytucja Stanów Zjednoczonych, stałoby się najwyższym prawem stanu, a ograniczenia federalnej konstytucji w zakresie sprawowania władzy stanowej byłyby bezsilnymi zwrotami" ${ }^{64}$. Zdaniem Collinsa stan zagrożenia epidemicznego nie znosi normalnych konstytucyjnych standardów orzeczniczych, lecz może uzasadniać czasowe ograniczenia praw i wolności konstytucyjnych w „ramach” tych standardów. W sprawie Jacobson Sąd Najwyższy oceniał sprzeczność obowiązku szczepień z prawami konstytucyjnymi wprost w niej niewysłowionymi (doktryna substantive due process), a nie z Free Exercise Clause, skoro w 1905 r. 1. poprawki do konstytucji w ogóle nie stosowano jeszcze wobec władzy stanowej. Według Collinsa precedens ze sprawy Jacobson mógłby mieć zastosowanie do przypadków zakazywania zgromadzeń religijnych w okresie pandemii COVID-19, gdyby skarżący powoływali się na substantive due process, ale nie gdy swoje zarzuty wywodzą z wyraźnie zapisanej w konstytucji wolności religijnej ${ }^{65}$.

Nie bez podstaw jest też stanowisko sędziego Petera Phippsa, że ocena konstytucyjności nawet prawa neutralnego religijnie powinna podlegać testowi ścisłemu, ilekroć prawo to ingeruje nie w jedną, lecz w dwie czy kilka konstytucyjnych wolności jednostki. Zdaniem Phippsa rozporządzenia wykonawcze zakazujące zgromadzeń religijnych są przykładem takiego właśnie prawa, gdyż ograniczają nie tylko wolność religijną, ale także wolność słowa czy ekspresji (tzw. koncepcja prawa hybrydowego) ${ }^{66}$.

\footnotetext{
64 Zob. Sterling v. Constantin, 287 U.S. 378, 397-98 (1932).

65 South Bay United Pentecostal Church, 959 F.3d 938, 942 (Collins, dissenting).

${ }_{66}$ Bullock, 806 F. App'x 157, 159 (Phipps, dissenting).
} 


\section{WNIOSKI KOŃCOWE}

Wydaje się, że głównym źródłem rozbieżności w orzecznictwie w omawianej kategorii spraw jest odmienne postrzeganie przez poszczególne sądy, a w zasadzie sędziów, samej religii, jej miejsca w życiu jednostki i społeczeństwa. Znajdowało to swój wyraz w uznawaniu lub nieuznawaniu zbiorowych praktyk religijnych za aktywność ,istotną” (essential) czy kwestię ,pierwszej potrzeby” (life sustaining).

W oparciu o studium orzecznictwa można odnieść wrażenie, że część sądów świadomie lub nieświadomie w swoim rozumowaniu kierowała się prywatystycznym i poniekąd strywializowanym wyobrażeniem religii, jako sprawy jednostkowego światopoglądu, czegoś zarezerwowanego na czas wolny, mogącego poczekać, zawieszalnego „dodatku” do życia, a nie jego konstytutywnego składnika ${ }^{67}$. Przejawem ignorancji części sądów odnośnie do natury aktów kultu było podkreślanie możliwości uczestniczenia wiernych w liturgii w sposób zdalny, tak jakby stanowiło to pełnowartościowy surogat osobistego w niej uczestnictwa. Dla kogoś uznającego sakramentalną wartość Eucharystii oglądanie w telewizji czy poprzez Internet mszy świętej nigdy nie będzie tożsame z czynnym partycypowaniem in personam. Wymowne jest również to, do czego porównywano religię ${ }^{68}$. Uzasadniając zakaz zgromadzeń religijnych sądy zestawiały je z rozrywką, tj. koncertami, pokazami filmowymi, widowiskami sportowymi, przedstawieniami teatralnymi. Nie przekonuje argumentacja sędziego Robertsa, jakoby u podstaw takiego, a nie innego zestawienia stała okoliczność, że w obu przypadkach chodzi o wydarzenia gromadzące dużą liczbę osób znajdujących się w bliskiej odległości przez dłuższy okres. Jak trafnie zauważył Sąd Apelacyjny dla 6 Okręgu, wcale nie jest tak, że w kościele przebywa się czasowo dłużej niż np. na spotkaniu pracowników w biurze czy na lotnisku ${ }^{69}$. Bardzo selektywnie też sędzia Roberts przywołał przykłady wyłączonych spod zakazów zgromadzeń, poprzestając na sklepach

${ }^{67}$ Por. Carter 1994; K. Jones, Former judge: coronavirus restrictions have a place, but religion is 'essential', https://www.catholicnewsagency.com/news/former-judge-coronavirus-restrictions-have-a-place-but-religion-is-essential-36424 [dostęp: 11.08.2020].

68 Por. Rothschild 2020, 289-291.

69 Roberts, 958 F.3d 409, 416. 
spożywczych, bankach i pralniach. Wystarczy wskazać kazus działalności wielkich centrów handlowych, aby pokazać nieadekwatność racjonalizacji, którą posłużył się Przewodniczący Sądu Najwyższego. W centrach handlowych gromadzą się bowiem setki osób, a czas przebywania wewnątrz nierzadko przekracza okres trwania nabożeństwa religijnego. Ponadto w doborze przykładów u Robertsa wyraźnie dostrzec można wymiar retoryczny i psycho-emocjonalny. Wygodniej było mu stwierdzić, że stanowe przepisy spod obostrzeń wyłączyły sklepy spożywcze, niż podać, że władza stanowa zezwoliła na normalną działalność sklepów monopolowych czy punktów sprzedaży marihuany.

Zagadnieniem interesującym dla socjologii religii i socjologii prawa jest okoliczność, że zdecydowana większość pozwów w omawianej kategorii spraw wniosły kościoły protestanckie, a nie Kościół Katolicki ${ }^{70}$. Mając na uwadze pojmowanie mszy świętej w teologii katolickiej można by spodziewać się, że to właśnie katolicy i ich duszpasterze będą w USA najsilniej protestować przeciwko zakazowi zgromadzeń religijnych ${ }^{71}$. Tymczasem wspólnota katolicka, a zwłaszcza jej duszpasterze, zasadniczo przyjęła początkowo w odniesieniu do stanowych przepisów postawę stricte legalistyczną. Niemal bez wyjątków ${ }^{72}$ zaniechanie przez kościelnych hierarchów w pierwszym okresie pandemii dochodzenia poszanowania wolności religijnej na drodze sądowej - postrzeganej przez nich jako działanie konfrontacyjne i sprzeczne z duchem koncyliacyjności - niejednokrotnie skutkowało tym, że gubernatorzy nie widzieli potrzeby znoszenia czy osłabiania obostrzeń wobec wspólnot religijnych, pomimo liberalizacji przepisów w odniesieniu do kolejnych obszarów gospodarki i stosunków społecznych. Milczenie środowisk religijnych w obliczu restrykcji było odbierane przez władze stanowe jako przyzwolenie na dalsze stosowanie represyjnych przepisów, bez względu na ich adekwatność do stopnia za-

70 We wszystkich rozpatrywanych sprawach sądowych skarżącymi były wspólnoty chrześcijańskie.

${ }^{71}$ M. Movesian, Religious liberty in COVID-19's wake, https://perma.cc/E2G6-SVDZ [dostęp: 11.08.2020].

72 Zob. C. Rousselle, Madison changes church reopening rules after Catholic bishop threatens lawsuit, https://www.catholicnewsagency.com/news/madison-changes-coronavirus-church-reopening-rules-after-catholic-bishop-threatens-lawsuit-22017 [dostęp: 11.08.2020]. 
grożenia i zmieniającej się dynamiki sytuacji epidemicznej. Poszanowanie wolności religijnej niekiedy wymaga dopominania się o nią. Po tym, jak biskupi diecezji Minneapolis oświadczyli, że wbrew prawu stanowemu otworzą dla swoich wiernych świątynie - nie mogąc doczekać się na odzew władzy wobec wielokrotnie ponawianych, uzasadnionych próśb zniesienia części obostrzeń - gubernator niedługo później zmienił przepisy zgodnie z oczekiwaniami osób wierzących ${ }^{73}$. Dopiero po silnych protestach władze hrabstwa Howard w stanie Maryland zniosły przepisy, które skutkowały zakazem podawania wiernym w czasie mszy świętej komunii świętej ${ }^{74}$.

Sądy wstrzymujące stosowanie przepisów reglamentujących zgromadzenia religijne zasadnie wskazały, że możliwość uczestniczenia we mszy świętej za pośrednictwem środków komunikacji elektronicznej nie czyni bezprzedmiotowymi roszczeń tych wiernych, którzy powołując się na konstytucyjną wolność religijną pragną osobiście wziąć udział w religijnym nabożeństwie w murach świątyni. Po pierwsze, nie wszystkie osoby posiadają dostęp do Internetu. Po drugie, co istotniejsze, część wierzących oglądanie internetowej transmisji mszy świętej nie postrzega jako wypełnienia religijnych obowiązków, w myśl słów Chrystusa „bo gdzie są dwaj albo trzej zebrani w imię moje, tam jestem pośród nich" (Mt 18:20). Ustawa zasadnicza gwarantuje, swobodne praktykowanie religii, a nie tylko prawo do wewnętrznej wiary"75. Sąd Apelacyjny dla 6 Okręgu słusznie wskazał, że nie jest jego rolą ani nie leży w jego kompetencji ocenianie tego, jak wierni pojmują swoją wiarę i jak się stosują do jej nakazów ${ }^{76}$. Podobnie Sąd Okręgowy dla Zachodniego Dystryktu Kentucky trafnie podkreślił, że konstytucja chroni prawo do praktykowania religii w sposób, w jaki komuś nakazuje to jego sumienie, a w zakresie sądowej kognicji nie leży różnicowanie tego co istotne i co nieistotne dla danej religii. Dla wielu osób religia nie jest czysto osobistą sprawą, której można oddawać się w zaciszu swo-

73 Minnesota bishops will reopen public Masses, defy state order, https://www.catholicnewsagency.com/news/minnesota-bishops-will-reopen-public-masses-defy-state-order-19583 [dostęp: 11.08.2020].

74 C. Rousselle, Maryland county lifts ban on Communion, https://www.catholicnewsagency.com/news/maryland-county-lifts-ban-on-communion-71034 [dostęp: 11.08.2020].

75 Trinity Lutheran Church of Columbia v. Comer, 137 S. Ct. 2012, 2026 (2017) (Gorsuch, J., concurring).

76 Maryville Baptist Church, 957 F.3d 610, 615. 
jego własnego pokoju ${ }^{77}$. Dla chrześcijan istotne są religijne zgromadzenia. Grecki termin na oznaczenie kościoła (ekklesia) dosłownie oznacza właśnie zgromadzenie ${ }^{78}$.

Z orzeczeń sądów, w których zakwestionowano konstytucyjność przepisów zabraniających zgromadzeń religijnych, przebija świadomość wagi praktyk religijnych dla osób wierzących. Jak podniósł Sąd Okręgowy dla Zachodniego Dystryktu Kentucky, w XVII w. tysiące chrześcijan opuściło Anglię i udało się do nieznanego „Nowego Świata”, aby tutaj pomimo trudnych warunków egzystencjalnych móc swobodnie wyznawać i praktykować swoją wiarę w zgodzie z własnym sumieniem bez obawy dyskryminacji i prześladowań. Imigranci ci byli jednym z wielu pokoleń doświadczających ucisku chrześcijan, dalekimi spadkobiercami tych starożytnych chrześcijan, których karano za uczestniczenie w Eucharystii. Ojcowie Założyciele świadomi zła nietolerancji i prześladowań mocą 1. poprawki do Konstytucji zagwarantowali każdemu wolność religijną. Swoboda sumienia i wyznania stała się odtąd jedną z cech konstytutywnych USA i Narodu amerykańskiego, choć na przestrzeni dekad nie zawsze jej przestrzegano w odniesieniu do poszczególnych mniejszościowych grup religijnych. Sąd powołując się na Alexisa de Tocqueville'a ochronę wolności religijnej potraktował jako gwarancję poszanowania także innych praw i wolności jednostki. Stan rzeczy, w którym udział we mszy świętej - także tej odprawianej na parkingu kościoła $\mathrm{z}$ wiernymi siedzącymi w swoich samochodach - jest kryminalizowany, przyrównał do niewyobrażalnych historii z utopijnej beletrystyki ${ }^{79}$. Inny sąd nawiązując do terminologii ,life sustaining” stwierdził, że nabożeństwa religijne „podtrzymują duszę"80. Kolejny sąd wskazał, że zaskarżone przepisy stawiały wiernych między Scyllą a Charybdą, zmuszając ich do wybierania między wiernością wierze a groźbą zarzutów kryminalnych ${ }^{81}$.

Ochrona zdrowia publicznego może wymagać ograniczenia praw i wolności jednostki, w tym wolności religijnej. Świadomym tego jest zde-

77 Por. Lee v. Weisman, 505 U.S. 577, 645 (1992) (Scalia, J., dissenting).

78 On Fire Christian Center v. Fischer, s. 14.

79 Ibidem, s. 6-7.

80 Maryville Baptist Church, 957 F.3d 610, 615.

81 Berean Baptist Church v. Cooper, s. 18. 
cydowana większość osób wierzących. W obliczu wagi zagrożenia oraz w imię odpowiedzialnej postawy obywatelskiej wierni ze zrozumieniem przyjęli limity osób w świątyniach oraz obostrzenia sanitarne. Władza odwołując się do solidaryzmu społecznego nie może jednak postępować w sposób dyskryminacyjny i traktować miejsc kultu religijnego bardziej surowo niż inne miejsca publiczne gromadzące osoby, jak choćby centra handlowe czy kasyna. W szczególności nie wolno jej założyć, że uczestnictwo w zbiorowych aktach kultu jest czymś drugorzędnym, mogącym poczekać, ustępując pierwszeństwa innym rzekomo ważniejszym czy pilniejszym formom aktywności i działalności społecznej. Dla wielu osób niemożność osobistego udziału w aktach kultu publicznego nie jest zwykłą niedogodnością, lecz źródłem głębokiego duchowego cierpienia. Władzy działającej w dobrych intencjach zdarza się przyjmować rozwiązania niesprawiedliwe i sprzeczne z konstytucyjnymi standardami. Kwestionowanie tych rozwiązań na drodze sądowej, czasami skutecznie, świadczy o dojrzałości danego porządku prawnego i kluczowej roli judykatywy w poszanowaniu podstawowych wolności i praw obywateli.

\section{BIBLIOGRAFIA}

Carter, Stephen. 1994. How American Law and Politics Trivialize Religious Devotion. New York: Doubleday.

Conklin, Michael. 2020. "«The Most Demanding Test Known to Constitutional Law»: Do Coronavirus Bans on Church Services Satisfy Religious Freedom Restoration Act Requirements?". Washburn Law Journal 60/1: 63-76, https:// contentdm.washburnlaw.edu/digital/collection/wlj/id/7277/rec/61.

Corbin, Caroline Mala. 2020. "Religious Liberty in a Pandemic". Duke Law Journal Online 70 (September), https://dlj.law.duke.edu/2020/09/religiouspandemic/.

Fallon, Richard H. 2019. The nature of constitutional rights: the invention and logic of strict judicial scrutiny. New York: Cambridge University Press.

Farber, Daniel. 2020. "The Long Shadow of Jacobson v. Massachusetts: Epidemics, Fundamental Rights, and the Courts". San Diego Law Review 57/4: 833-863, https://digital.sandiego.edu/sdlr/vol57/iss4/1/.

Greenawalt, Kent. 2009. Religion and the Constitution. Vol. 1. Free Exercise and Fairness. Princeton: Princeton University Press. 
Hodge, James G. 2015. "Respecting Religious Freedoms and Protecting the Public's Health". Law and the Public's Health 130(5): 546-549.

Kudła, Weronika. 2018. Wrogość wobec religii. Ostrzeżenia ze strony Sądu Najwyższego USA. Kraków: Księgarnia Akademicka.

Laycock, Douglas, Steven T. Collis. 2016. "Generally Applicable Law \& the Free Exercise of Religion”. Nebraska Law Review 95/1: 1-27.

Małajny, Ryszard. 1992. Mur separacji. Państwo a kościół w Stanach Zjednoczonych Ameryki. Katowice: Wydawnictwo Uniwersytetu Śląskiego.

McConnell, Michael W., Thomas C. Berg, Christopher C. Lund. 2016. Religion and the constitution. New York: Wolters Kluwer.

Parmet, Wendy. 2020. "Rediscovering Jacobson in the Era of COVID-19". Boston University Law Review Online 100: 117-133.

Potz, Maciej. 2015. Granice wolności religijnej. Toruń: Wydawnictwo UMK.

Reiss, Rubinstein Dorit, Madeline Thomas. 2020. "More Than a Mask: Stay-AtHome Orders and Religious Freedom". San Diego Law Review 57/4: 947-972, https://digital.sandiego.edu/sdlr/vol57/iss4/4/.

Rothschild, Zalman. 2020. "Free Exercise's Lingering Ambiguity". California Law Review Online 11: 282-295.

Stephens, Otis H., John M. Scheb. 2008. American constitutional law. Vol. 1. Sources of Power and Restraint. Belmont: Thomson/Wadsworth.

Stoll-DeBell, Kirstin, Nancy L. Dempsey, Bradford E. Dempsey. 2009. Injunctive relief: temporary restraining orders and preliminary injunctions. Chicago: American Bar Association.

Wiley, Lindsay F., Stephen I. Vladeck. 2020. "Coronavirus, Civil Liberties, and the Courts: The Case Against "Suspending" Judicial Review". Harvard Law Review Forum 133/9: 179-198.

\section{RESTRICTION OF RELIGIOUS FREEDOM DURING THE FIRST PERIOD OF THE COVID-19 PANDEMIC IN THE LIGHT OF U.S. CASE LAW}

Abstract

The article presents a critical analysis of the U.S. federal court rulings regarding restrictions on freedom of religion during the COVID-19 pandemic. The subject of judicial control were the executive orders prohibiting public religious gatherings or limiting the number of participants. The author shares the view of the part of the courts which assumed that the laws introducing stricter restric- 
tions for churches and religious assemblies than for other comparable places and secular gatherings, in order to be constitutional, need to simultaneously pursue the compelling interest of the state and constitute proportional measures. While the protection of public health is a compelling interest of the government, the total prohibition of in-person church services or limiting religious gatherings to only a few people seem to violate the criterion of the least restrictive measure. When deciding what forms of social activity and businesses to exclude from the ban on public gatherings, the authorities cannot discriminatively assume that religious services are something secondary and not very urgent, especially if the same authorities consider the operation of e.g. liquor stores or shopping malls as "essential" or "life sustaining".

Key words: freedom of religion; COVID-19; Constitution of the United States; federal case law; the United States; SARS-CoV-2 
